BIOFARM

Jurnal Ilmiah Pertanian

ISSN Print: 0216-5430; ISSN Online: 2301-6442

Vol. 16, No. 2, Oktober 2020

\title{
Uji Model Produksi Cobb-Douglas pada Pertumbuhan dan Hasil Selada dengan Budidaya Hidroponik Sistem Rakit Apung
}

\author{
Test the Cobb-Douglas Production Model on the Growth and Yield of Lettuce \\ with Hydroponic Cultivation of Floating Raft Systems
}

\author{
Arbina Satria Afiatan ${ }^{1 *}$, Noor Farid ${ }^{2}$ dan Ardiansyah ${ }^{2}$ \\ ${ }^{1}$ Program Studi Agroteknologi, Fakultas Pertanian, Universitas Pekalongan \\ ${ }^{2}$ Fakultas Pertanian, Universitas Jenderal Soedirman Purwokerto \\ *Korespondensi Penulis: arbinaafiatan@gmail.com
}

\begin{abstract}
ABSTRAK
Penelitian ini bertujuan untuk mengetahui: pertumbuhan dan hasil selada berbagai varietas yang ditanam dengan budidaya hidroponik sistem rakit apung, pertumbuhan dan hasil selada berbagai nilai EC yang ditanam dengan budidaya hidroponik sistem rakit apung, kesesuaian model Cobb-Douglas untuk produksi selada hidroponik sistem rakit apung. Penelitian dilaksanakan di screen house Pondok Pesantren Darussalam, Desa Dukuhwaluh, Kecamatan Kembaran, Kabupaten Banyumas. September sampai November 2016. Penelitian ini merupakan percobaan rumah kaca (screen house) dengan menggunakan rancangan petak terbagi (split plot), petak utama terdiri dari nilai $E C(P)$ dan anak petak terdiri dari varietas selada (V). Petak utama adalah nilai EC (P), terdiri dari P1 = EC 2; P2 = EC 3; P3 = EC 4, Anak petak adalah varietas (V), terdiri dari $\mathrm{V} 1=$ varietas new grand rapid; $\mathrm{V} 2=$ varietas red ava; $\mathrm{V} 3=$ varietas chris green. Berdasarkan hasil penelitian menunjukan bahwa varietas menunjukan hasil sangat nyata pada variabel jumlah daun, volume akar, kadar klorofil, bobot basah tanaman, bobot basah akar dan varietas selada yang memberikan hasil terbaik untuk sistem hidroponik rakit apung dengan melihat variabel tinggi tanaman, jumlah daun, volume akar, kadar klorofil, panjang akar, bobot basah tanaman, dan bobot basah akar adalah varietas Chris green, perlakuan nilai EC menunjukan hasil sangat nyata pada variabel $\mathrm{N}$ total jaringan dengan nilai EC 4 dan hasil yang diperoleh yaitu 1,32\%, model persamaan matematik dengan fungsi Cobb-Douglas belum bisa memvalidasi data penelitian dikarenakan error tinggi, sehingga Y Model tidak mengikuti Y Observasi
\end{abstract}

Kata kunci : Permodelan, selada, hidroponik rakit apung

\section{ABSTRACT}

This study aims to determinate: growth and yield of various varieties of lettuce planted with hydroponic cultivation of floating rafting raft system, growth and yield of various EC grades of lettuce grown with hydroponic cultivation of floating raft system, suitability of the Cobb-Douglas model for the production of hydroponic lettuce floating raft system. The research was conducted at the screen house of the Islamic boarding school Darussalam, Dukuhwaluh village, Kembaran District, Banyumas Regency. September to November 2016. This research is a screen house using split plot design, the main plot consists of EC $(P)$, consisting of $P 1=E C 2 ; P 2=E C 3 ; P 3=E C 4$, subplot are varieties $(V)$, consisting of $V 1=$ New grand rapids varieties; V2 $=$ Red ava varieties; $V 3=$ Chris green varieties. Based on the result of the study showed that the varieties showed differences in the number of leaves, root volume, chlorophyll content, plant wet weight, root wet weight and lettuce varieties which gave the best results for floating raft hydroponic systems by looking at plant height, leaf number, root volume, chlorophyll content, root length, plant wet weight, and root wet weight were Chris green varieties, the treatment of $E C$ values shows the difference in the total $N$ variable of the network with the value of EC 4. and the results obtained are $1.32 \%$, the model of mathematical equations with Cobb-Douglas functions has not been able to validate research data due to high errors, so that the Y Model does not follow Y Observation

Keyword : Modeling, lettuce, hydroponic floating rafts

\section{PENDAHULUAN}

Indonesia merupakan negara yang kaya akan keanekaragaman hayati termasuk diantaranya jenis tanaman hortikultura. Hortikultura merupakan salah satu komoditas pertanian yang mempunyai potensi besar untuk dikembangkan di Indonesia karena merupakan negara dengan iklim tropis (Riris, 2009). Selada (Lactuca sativa L.) merupakan salah satu tanaman sayur yang biasa ditanam di daerah beriklim sedang maupun daerah tropika dan termasuk tanaman semusim yang banyak mengandung air. 
Sayuran ini biasa dikonsumsi sebagai Ialap mentah dan dibuat salad (Sastradiharja, 2011).

Selada dapat ditanam secara hidroponik atau tidak harus secara konvensional. Cara penanaman ini banyak diusahakan oleh pengusaha agribisnis sayuran yang memasok pasar tertentu untuk kalangan menengah ke atas. Pada mulanya hidroponik diartikan sebagai bercocok tanam dalam media air, dalam perkembangannya bertanam dalam media air ini meluas ke penggunaan media lain seperti pasir, kerikil, aneka bebatuan, sabut, jerami, dan beberapa media lainnya (Haryanto, 2003).

Bercocok tanam dengan sistem hidroponik mutlak memerlukan pupuk sebagai sumber makanan bagi tanaman. Pupuk dalam sistem hidroponik disebut larutan nutrisi. Nutrisi merupakan hal yang sangat penting untuk pertumbuhan dan kualitas hasil tanaman hidroponik, sehingga harus tepat dari segi jumlah, komposisi ion nutrisi dan suhu. Pupuk diberikan dalam bentuk larutan yang harus mengandung unsur makro dan mikro (Lingga, 2005). Menurut Nugraha (2014) perlakuan dengan menggunakan pupuk $A B$ mix menghasilkan pertumbuhan vegetatif dan hasil panen terbaik pada tanaman bayam, pakchoy dan selada. Kandungan pupuk $A B$ mix diduga memiliki komposisi seimbang yang dibutuhkan oleh tanaman. Mas'ud (2009) menyampaikan bahwa nutrisi hidroponik yang tepat akan memberikan hasil yang optimal bagi pertumbuhan tanaman selada. Oleh karena itu dilakukannya penelitian tentang pengujian beberapa nutrisi hidroponik pada selada (Lactuca sativa L.) dengan teknologi hidroponik dengan membandingkan tiga nilai EC. Salah satu tipe hidroponik yang dapat dilakukan untuk membandingkan dosis EC adalah tipe rakit apung.

Model adalah contoh sederhana dari sistem dan menyerupai sifat-sifat sistem yang dipertimbangkan, tetapi tidak sama dengan sistem. Penyederhanaan dari sistem sangat penting agar dapat dipelajari secara seksama. Model dikembangkan dengan tujuan untuk studi tingkah-laku sistem melalui analisis rinci akan komponen atau unsur dan proses utama yang menyusun sistem dan interaksinya antara satu dengan yang lain. Jadi pengembangan model adalah suatu pendekatan yang tersedia untuk mendapatkan pengetahuan yang layak akan sistem tanaman. Model berperan penting dalam pengembangan teori karena berfungsi sebagai konsep dasar yang menata rangkaian turan yang digunakan untuk menggambarkan sistem. Salah satu model pengukuran produktivitas yang sering digunakan adalah pengukuran berdasarkan pendekatan fungsi produksi Cobb-Douglas, yaitu suatu fungsi atau persamaan yang melibatkan dua variabel atau lebih, variabel yang satu disebut variabel independent $(\mathrm{Y})$ dan yang lain disebut variabel dependent (X) (Jones et al, 1987).

\section{BAHAN DAN METODE}

Penelitian dilaksanakan di screen house Pondok Pesantren Darussalam, Desa Dukuhwaluh, Kecamatan Kembaran, Kabupaten Banyumas pada ketinggian tempat \pm 200 meter di atas permukaan laut (dpl). Persiapan dan analisis dilaksanakan di Laboratorium IImu Tanahdan Laboratorium Agronomi dan Hortikultura Fakultas Pertanian Universitas Jenderal Soedirman. Penelitian dimulai pada bulan September sampai November 2016.

Bahan-bahan yang digunakan pada penelitian ini adalah air, rockwoll, benih selada varietas new grand rapid, red ava, chris green dan pupuk ab mix. Alat-alat yang digunakan antara lain: Green house piggyback, pot percobaan, bak persemaian, net pot, ember, pengaduk kayu, Styrofoam, pipa paralon, pH meter, EC meter, Thermohygrometer, timbangan analitik, klorofil meter, sprayer, peralatan laboratorium (botol timbangan, botol semprot, labu piknometer, timbangan analitik, alat-alat gelas (cawan porselin, lampu spirtus, pipet, gelas ukur, gelas beker, thermometer dan lain-lain) penggaris, label, dan alat tulis. 
Penelitian ini merupakan percobaan rumah kaca (screen house) dengan menggunakan rancangan petak terbagi (split plot), petak utama terdiri dari nilai EC $(P)$ dan anak petak terdiri dari varietas selada (V). Petak utama adalah nilai EC $(P)$, terdiri dari : $\mathrm{P} 1=$ nilai $\mathrm{EC} 2 ; \mathrm{P} 2=$ nilai $\mathrm{EC} 3 ; \mathrm{P} 3=$ nilai

Variabel yang diamati kandungan tinggi tanaman, jumlah daun, luas daun, volume akar, kadar klorofil, panjang akar, bobot basah tanaman, bobot basah akar, dan Serapan N tanaman.

Data hasil pengamatan dianalisis dengan uji $F$ dan apabila terdapat keragaman antar perlakuan dilanjutkan UJGD (Uji Jarak Ganda Duncan) pada taraf uji 5\%. Analisis data permodelan menggunakan data bobot basah tanaman dan data jumlah daun. Data bobot basah tanaman yang diambil menggunakan sampel tanaman tiap varietas dari tiap perlakuan larutan EC pada tiap ulangan dan data jumlah daun yang diambil menggunakan sampel tanaman tiap varietas dari tiap perlakuan larutan EC pada tiap ulangan, data EC diambil dari perlakuan larutan EC yang dicobakan, yaitu 2, 3, 4, data Varietas diambil dari 3 jenis varietas yang digunakan selama proses penelitian, data $\mathrm{pH}$ diambil dari nilai derajat keasaman yang digunakan selama proses penelitian, data
EC 4. Anak petak adalah varietas selada (V), terdiri dari : $\mathrm{V} 1$ = varietas new grand rapid; V2 = varietas red ava; $\mathrm{V} 3$ = varietas chris green. Berdasarkan perlakuan diatas diperoleh 9 kombinasi perlakuan dengan ulangan 3 kali, sehingga secara total terdapat 27 unit percobaan.

suhu dan kelembaban diambil dari alat pengukur selama proses penelitian.

Berdasarkan penjelasan tersebut, maka model fungsi produksi Cobb-Douglas untuk mengoptimasi produktivitas selada dengan cara hidroponik secara matematis dapat ditulis dengan persamaan sebagai berikut : $\mathrm{Y}=\mathrm{a}(\mathrm{Tb} 1)$ (pHb2) (varb5) $\mathrm{e}(\mathrm{u}+(\mathrm{b} 3(\mathrm{EC}))(\mathrm{RHb} 4)$ (Keterangan: $\mathrm{Y}=$ Hasil Tanaman Selada; a,b1,b2,b3,b4,b5= Variabel parameter; $\mathrm{T}=$ Suhu; $\mathrm{pH}=$ Kelembaban; $\mathrm{Var}=$ Varietas yang digunakan; $\mathrm{EC}=$ Nilai $\mathrm{EC}$ yang digunakan; $\mathrm{RH}=$ Kelembaban).

\section{HASIL DAN PEMBAHASAN}

Hasil analisis sidik ragam pengaruh nilai EC (electrical conductivity) dan hasil tiga varietas selada (Lactuca sativa L) pada hidroponik rakit apung dapat dilihat pada tabel 1.

Tabel 1. Hasil sidik ragam nilai EC (Electrical Conductivity) dan Varietas selada terhadap variabel pengamatan

\begin{tabular}{|c|c|c|c|c|}
\hline no & Variabel & $\mathrm{P}$ & V & $P \times V$ \\
\hline 1 & Tinggi tanaman $(\mathrm{cm})$ & tn & tn & tn \\
\hline 2 & Jumlah daun (helai) & tn & ** & tn \\
\hline 3 & Luas Daun (mm2) & tn & tn & tn \\
\hline 4 & Volume Akar (ml) & tn & ** & tn \\
\hline 5 & Kadar Klorofil $(\mu \mathrm{mol} / \mathrm{m} 2)$ & tn & ** & tn \\
\hline 6 & Panjang Akar $(\mathrm{cm})$ & tn & tn & tn \\
\hline 7 & Bobot Basah Tanaman (g) & tn & ** & tn \\
\hline 8 & Bobot Basah Akar (g) & tn & ** & tn \\
\hline 9 & $\mathrm{~N}$ total jaringan (\%) & ** & tn & tn \\
\hline
\end{tabular}

Keterangan : $\mathrm{P}=$ nilai $\mathrm{EC}, \mathrm{V}=$ Varietas tanaman, $\mathrm{P} \times \mathrm{V}=$ interaksi nilai $\mathrm{EC}$ dengan varietas tanaman, $\mathrm{tn}=$ tdak nyata, ${ }^{*}=$ nyata, ${ }^{* *}=$ sangat nyata.

Berdasarkan hasil sidik ragam pada tabel 1 menunjukan bahwa perlakuan nilai EC berpengaruh sangat nyata pada variabel serapan $\mathrm{N}$, namun tidak berpengaruh pada variabel lainnya. Nilai EC yang diberikan tidak memberi pengaruh terhadap variabel tinggi tanaman, jumlah daun, luas daun, volume akar, kadar klorofil, panjang akar, bobot basah tanaman, dan bobot basah akar. Variabel tinggi tanaman menujukan hasil tidak berbeda nyata pada semua perlakuan yang dicoba.
Variabel rata-rata jumlah daun menunjukan hasil berbeda sangat nyata pada perlakuan varietas, namun perlakuan nilai EC dan interaksi antara kedua perlakuan menunjukkan hasil tidak berbeda nyata. Variabel luas daun menunjukan hasil tidak berbeda nyata pada semua perlakuan yang dicoba. Variabel volume akar dan variabel kadar klorofil menunjukan hasil berbeda sangat nyata pada perlakuan varietas, namun perlakuan nilai EC dan interaksi antara kedua 
perlakuan menunjukkan hasil tidak berbeda nyata. Variabel panjang akar menunjukan hasil tidak berbeda nyata pada semua perlakuan yang dicoba. Variabel bobot basah tanaman dan variabel bobot basah akar menunjukan hasil berbeda sangat nyata pada perlakuan varietas, namun perlakuan nilai EC dan interaksi antara kedua perlakuan menunjukkan hasil tidak berbeda nyata.Variabel $\mathrm{N}$ Total menunjukan perlakuan nilai EC berpengaruh sangat nyata namun perlakuan varietas yang dicoba dan interaksi antara kedua perlakuan menunjukkan hasil tidak berpengaruh nyata.

Nilai EC yang diberikan tidak memberikan pengaruh terhadap semua variabel yang dicobakan yaitu tinggi tanaman, jumlah daun, luas daun, volume akar, kadar klorofil, panjang akar, bobot basah tanaman dan bobot basah akar. Nilai EC yang tidak berpengaruh terjadi karena nilai EC yang diberikan pada tanaman selada masih dapat diserap baik untuk proses pertumbuhan. Menurut (Hochmuth, 2003) tidak ada satu jenis formula larutan nutrisi larutan yang berlaku untuk semua komoditas. Beberapa faktor penting dalam menentukan formula nutrisi hidroponik adalah : 1). Garam yang mudah larut dalam air, 2). Kandungan sodium, klorida, ammonium dan nitrogen organik atau unsur-unsur yang tidak dibutuhkan untuk pertumbuhan tanaman harus diminimalkan, 3). Komposisi digunakan bahan yang bersifat tidak antagonis satu dengan yang lainnya dan dipilih yang ekonomis. Sejalan dengan hal tersebut, Erina (2007) juga menjelaskan bahwa peningkatan EC tidak bersifat linier dimana pemberian larutan nutrisi dengan kepekatan yang tinggi jika melebihi batas toleransi akan menyebabkan penurunan hasil.

\section{A. Perbedaan Tiga Varietas Selada terhadap Variabel Pertumbuhan 1. Jumlah Daun \\ Daun merupakan organ penghasil} fotosintat utama. Jumlah daun yang banyak akan menyediakan tempat fotosintesis lebih banyak, sehingga akan diperoleh fotosintat yang lebih banyak. Jumlah daun berkaitan erat dengan tinggi tanaman, karena daun merupakan organ yang terletak pada buku batang selada (Manuhuttu et al., 2014).

Tabel 2. Perbedaan pertumbuhan tanaman selada varietas tiga

\begin{tabular}{lcrl}
\hline Variabel & $\begin{array}{l}\text { Jumlah } \\
\text { Daun } \\
\text { (helai) }\end{array}$ & $\begin{array}{c}\text { Volume } \\
\text { Akar }(\mathrm{ml})\end{array}$ & $\begin{array}{l}\text { Kadar } \\
\text { Klorofil } \\
(\mu \mathrm{mol} / \mathrm{m} 2)\end{array}$ \\
\hline New grand rapids & $9,77 \mathrm{~b}$ & $8,22 \mathrm{~b}$ & $5,07 \mathrm{~b}$ \\
Red ava & $9,22 \mathrm{~b}$ & $7,77 \mathrm{~b}$ & $5,50 \mathrm{~b}$ \\
Chris green & $23,66 \mathrm{a}$ & $12,88 \mathrm{a}$ & $8,68 \mathrm{a}$ \\
\hline
\end{tabular}

Keterangan : Angka yang diikuti huruf yang sama pada kolom yang sama, berarti tidak berbeda nyata berdasarkan UJGD pada taraf 5\%.

Hasil uji varian (Tabel 2) menunjukan jumlah daun terbanyak yaitu pada varietas Chris green (V3) yaitu 23,66 dibandingkan dengan varietas New grand rapids (V1) yaitu 9,77 dan varietas Red ava (V2) yaitu 9,22. Tingginya jumlah daun pada varietas Chris green (V3) dipengaruhi karena varietas selada Chris green (V3) memiliki potensi atau sifat genetik yang berbeda seperti berpotensi berdaun lebih banyak dibandingkan varietas selada lainnya, hal ini diperkuat oleh pendapat dari Wasonowati et al., (2013) yang menyatakan bahwa potensi setiap varietas berpengaruh terhadap kemampuan tanaman untuk tumbuh dan berkembang. Mendukung pernyataan tersebut, Bastian et al., (2013) menyampaikan bahwa jumlah daun yang tinggi disebabkan unsur hara nitrogen yang terkandung didalam larutan nutrisi, karena nitrogen adalah komponen utama dari berbagai substansi penting didalam pembentukan daun tanaman. Nitrogen juga dibutuhkan untuk membentuk senyawa penting seperti klorofil, asam nukleat dan enzim.

\section{Volume Akar}

Akar merupakan organ vegetatif utama yang memasok air, mineral dan bahanbahan yang penting untuk pertumbuhan dan perkembangan tanaman. Walaupun memiliki sumbangan yang sangat penting, seringkali akar tidak diperdulikan karena tidak tampak 
(Gardner et al., 2007). Volume akar merupakan respon morfologi yang penting dalam proses adaptasi tanaman terhadap kekurangan air (Budiasih, 2009).

Hasil uji varian pada Tabel 2 menunjukan bahwa nilai volume akar tertinggi terdapat pada varietas Chris green (V3) sebesar 12,88 $\mathrm{ml}$ dibandingkan dengan varietas New grand rapids (V1) yaitu sebesar 8,22 $\mathrm{ml}$ dan varietas Red ava (V2) yaitu sebesar $7,77 \mathrm{ml}$. Mendukung data tersebut Palupi dan Dedywiryanto (2008) menyatakan bahwa tanaman yang memiliki volume akar tinggi, akan mampu mengarbsorbsi air lebih banyak sehingga mampu bertahan pada kondisi kekurangan air. Morgan (2000), menyatakan bahwa tanaman selada dapat tumbuh dengan optimal jika faktor yang mempengaruhinya terpenuhi, diantaranya adalah unsur hara dan media tumbuh yang mendukung pertumbuhan akar.

\section{Kadar Klorofil}

Menurut Sulistyaningsih et al., (2005), salah satu pendekatan untuk mengetahui jumlah klorofil daun adalah dengan mengukur tingkat kehijauan daun. Daun yang lebih hijau umumnya memiliki kandugan klorofil yang tinggi. Senada dengan hal tersebut, Harjoko (2007) menyatakan bahwa klorofil daun adalah pigmen warna hijau daun dalam tanaman yang terdapat di dalam kloroplas dan berperan dalam proses fotosintesis, semakin banyak kandungan klorofil pada daun akan meningkatkan proses fotosintesis.

Hasil uji varian pada Tabel 2 menunjukan bahwa varietas Chris green (V3) mempunyai kadar klorofil tertinggi yaitu sebesar $8,68 \mu \mathrm{mol} / \mathrm{m} 2$ dibandingkan dengan varietas New grand rapids (V1) yaitu sebesar $5,07 \mu \mathrm{mol} / \mathrm{m} 2$ dan varietas Red ava (V2)yaitu sebesar $5,50 \mu \mathrm{mol} / \mathrm{m} 2$. Mendukung data tersebut Ruhnayat (2007) menyampaikan bahwa kandungan klorofil yang tinggi pada tanaman memacu penangkapan cahaya yang digunakan sebagai energi dalam fotosintesis semakin baik sehingga hal ini mendorong proses fotosintesis pada tanaman semakin meningkat sehingga diperoleh laju pertumbuhan tanaman yang semakin baik

\section{B. Perbedaan Tiga Varietas Selada terhadap Variabel Hasil}

\section{Bobot Basah Tanaman}

Bobot basah tanaman menunjukan besarnya kandungan air dan bahan organik yang terkandung dalam jaringan atau organ tanaman, bobot segar umumnya digunakan sebagai petunjuk yang memberikan ciri pertumbuhan (Kastono et al., 2005).

Tabel 3. Perbedaan hasil tanaman pada tiga varietas selada

\begin{tabular}{lcc}
\hline \multicolumn{1}{c}{ Variabel } & $\begin{array}{c}\text { Bobot } \begin{array}{c}\text { Basah } \\
\text { Tanaman } \\
(\mathrm{g})\end{array} \\
\text { New grand rapids }\end{array}$ & $\begin{array}{c}\text { Bobot Basah } \\
\text { Akar } \\
(\mathrm{g})\end{array}$ \\
Red ava & $32,08 \mathrm{~b}$ & $7,45 \mathrm{~b}$ \\
Chris green & $27,32 \mathrm{~b}$ & $8,34 \mathrm{~b}$ \\
\hline
\end{tabular}

Keterangan : Angka yang diikuti huruf yang sama pada kolom yang sama, berarti tidak berbeda nyata berdasarkan UJGD pada taraf $5 \%$.

Hasil analisis varian (tabel 3) pada bobot basah tanaman menunjukkan hasil sangat nyata dengan hasil tertinggi terdapat pada varietas Chris Green (V3) sebesar 58,62 $\mathrm{g}$, dibandingkan varietas New grand rapids (V1) yaitu sebesar $32,08 \mathrm{~g}$ dan varietas Red ava (V2) yaitu sebesar $27,32 \mathrm{~g}$. Mendukung data tersebut, Suleman (2013) mengatakan bahwa tinggi tanaman dan jumlah daun berpengaruh pada bobot tanaman segar, semakin besar tinggi tanaman dan semakin banyak jumlah daun, maka bobot tanaman semakin meningkat.

Menurut Lahadassy et al., (2007), untuk mencapai bobot segar tanaman yang optimal, tanaman masih membutuhkan banyak energy maupun unsur hara agar peningkatan jumlah maupun ukuran sel dapat 
mencapai optimal serta memungkinkan adanya peningkatan kandungan air tanaman yang optimal pula. Senada dengan hal tersebut Sitompul dan Guritno (2005) menyatakan bahwa perbedaan susunan genetik merupakan salah satu faktor penyebab keragaman penampilan tanaman. Program genetik yang akan diekspresikan pada berbagai sifat tanaman mencakup morfologi tanaman yang menghasilkan keragaman pertumbuhan tanaman. Keragaman penampilan tanaman akibat perbedaan susunan genetik selalu mungkin terjadi sekalipun bahan tanaman yang digunakan berasal dari jenis tanaman yang sama.

\section{Bobot Basah Akar}

Menurut Sitompul dan Guritno (2005) hubungan akar dengan tajuk mula-mula lebih banyak ditekankan dari segi morfogenetik seperti dalam pandangan semakin banyak akar semakin baik hasil tanaman. Tetapi tanaman yang tumbuh dalam keadaan kurang air akan membentuk akar yang lebih banyak dengan hasil yang lebih rendah dari tanaman yang tumbuh dalam cukup air.

Hasil analisis varian tabel 3 pada bobot basah akar menunjukkan beda nyata dengan hasil tertinggi terdapat pada varietas Chris Green (V3) dengan nilai bobot basah akar 12,37 g dibandingkan varietas New grand rapids (V1) yaitu sebesar 7,45 g dan varietas Red ava (V2) yaitu sebesar $8,43 \mathrm{~g}$. Nilai bobot basah akar pada tiap varietas berbeda karena tiap varietas memiliki faktor genetik yang berbeda, Jasmi et al., (2013) menyatakan bahwa faktor genetik tanaman sebagai varietas unggul dimana setiap varietas memiliki kemampuan yang berbeda dari tempat tumbuh aslinya karena varietas merupakan faktor utama untuk menentukan tinggi rendahnya suatu produksi, didukung juga oleh faktor lain yaitu lingkungan dimana varietas merupakan sekumpulan individu tanaman yang dapat dibedakan oleh setiap sifat (morfologi, fisiologi, kimia dan lain-lain).

Tabel 4. Perbedaan hasil tanaman pada tiga nilai EC

Nilai EC

$\mathrm{N}$ total $(\%)$

\begin{tabular}{lr}
\hline (P1) & $1,28 \mathrm{~b}$ \\
$3(\mathrm{P} 2)$ & $1,31 \mathrm{a}$ \\
$4(\mathrm{P} 3)$ & $1,32 \mathrm{a}$
\end{tabular}

Keterangan : Angka yang diikuti huruf yang sama pada kolom yang sama, berarti tidak berbeda nyata berdasarkan UJGD pada taraf $5 \%$.

\section{Serapan $\mathbf{N}$}

Menurut Sunu dan Wartoyo (2006) nitrogen penting sebagai penyusun enzim yang sangat besar peranannya dalam proses metabolisme tanaman, karena enzim tersusun dari protein. Sebagai pelengkap bagi peranannya dalam sintesa protein, Nitrogen merupakan bagian tak terpisahkan dari molekul klorofil.

Hasil analisis varian pada Tabel 3 menunjukkan perlakuan nilai EC dengan hasil tertinggi terdapat pada perlakuan nilai EC 4 yaitu sebesar 1,32\% N/tanaman dibandingkan dibandingkan nilai EC 3 yaitu sebesar 1,31\% $\mathrm{N} /$ tanaman dan perlakuan nilai EC 2 yaitu sebesar 1,28\% N/tanaman. Plaster (2003) mengatakan bahwa nitrogen lebih diperlukan dalam menunjang pertumbuhan bagian vegetatif dibandingkan generatif dan penting bagi tanaman sayuran yang dikonsumsi bagian tajuknya, pemberian nitrogen dalam jumlah yang cukup, menghasilkan tanaman yang vigor dan ukuran daun yang besar.

\section{Permodelan Persamaan Matematika}

Untuk mencapai tujuan yaitu mengetahui model matematik dari budidaya tanaman selada secara hidroponik berdasarkan 3 nilai EC dan 3 jenis varietas digunakan alat analisis berupa persamaanpersamaan yang mengacu pada persamaan Cobb-Douglas yang diolah dengan aplikasi solver pada program Microsoft excel (Soekartawi, 1993). 
Grafik model matematik bobot basah tanaman varietas 1 disajikan pada gambar 10 , 11, dan 12, grafik model matematik bobot basah tanaman varietas 2 disajikan pada gambar 13, 14, dan 15 sedangkan untuk grafik model matematik bobot basah tanaman varietas 3 disajikan pada gambar 16,17, dan 18. Hasil analisis persamaan matematik bobot basah tanaman dari 3 varietas disajikan dalam tabel 1 sampai dengan 8 .

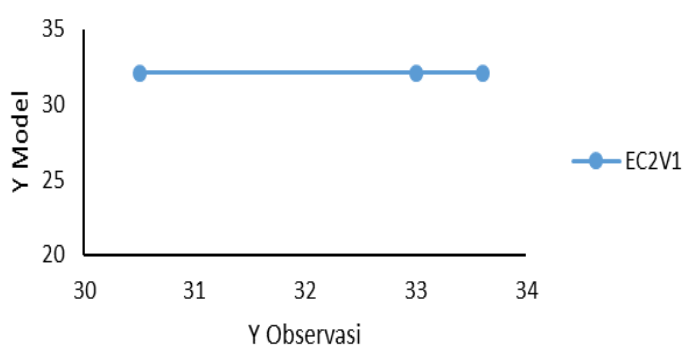

Gambar 10. Grafik Permodelan Matematik Bobot Basah Tanaman Selada Varietas 1 dengan Perlakuan EC2

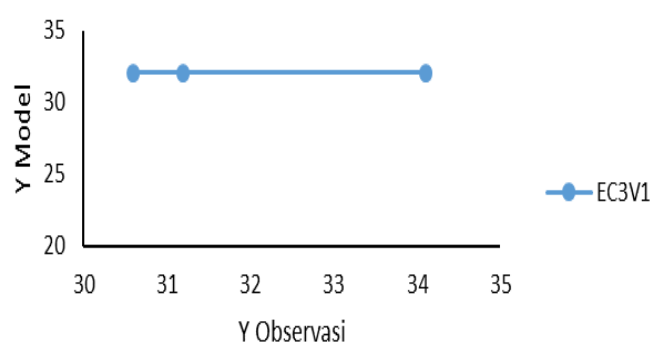

Gambar 11. Grafik Permodelan Matematik Bobot Basah Tanaman Selada Varietas 1 dengan Perlakuan EC3

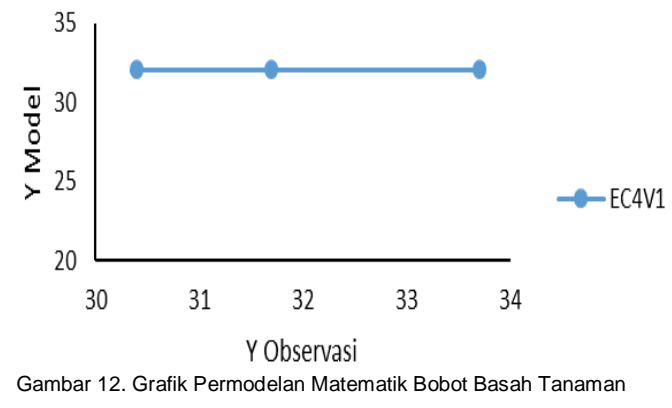

Selada Varietas 1 dengan Perlakuan EC4

Pengaruh perlakuan nilai EC 2 pada bobot basah tanaman selada varietas 1 menunjukan hasil $Y$ Model yang sama yaitu 32, 0903 dari semua $Y$ Observasi yang ada yaitu ulangan $1 \quad(33,6)$ ulangan $2(33)$ dan ulangan $3(30,5)$. Perlakuan nilai EC 3 pada bobot basah tanaman selada varietas 1 menunjukan hasil $Y$ Model yang sama yaitu 32, 0911 dari semua $Y$ Observasi yang ada yaitu ulangan $1(30,6)$; ulangan $2(31,2)$; dan ulangan $3(34,1)$. Perlakuan nilai EC 4 pada bobot basah tanaman selada varietas 1 menunjukan hasil $Y$ Model yang sama yaitu 32, 0918 dari semua $Y$ Observasi yang ada yaitu ulangan $1(31,7)$ ulangan $2(30,4)$ dan ulangan $3(33,7)$.
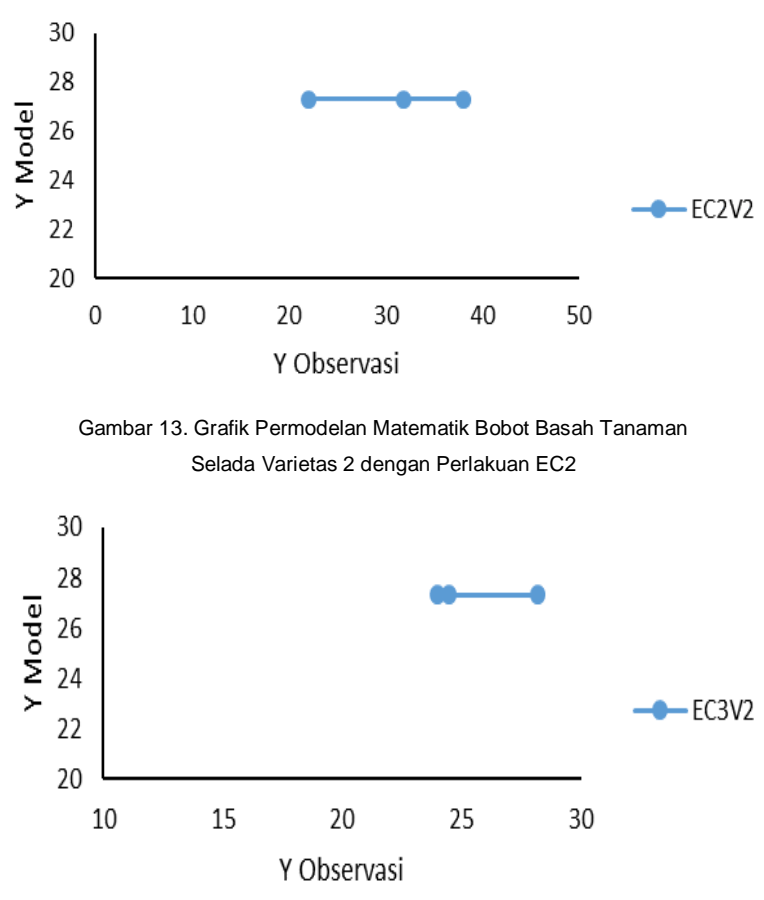

Gambar 14. Grafik Permodelan Matematik Bobot Basah Tanaman Selada Varietas 2 dengan Perlakuan EC3

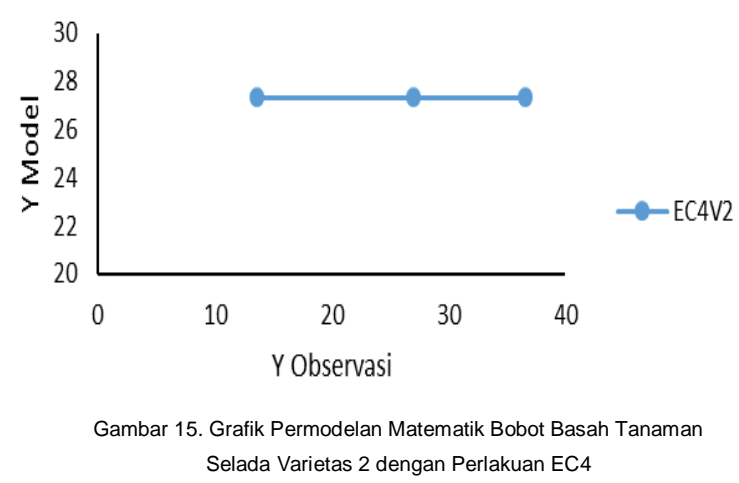

Pengaruh perlakuan nilai EC 2 pada bobot basah tanaman selada varietas 2 menunjukan hasil $Y$ Model yang sama yaitu 27, 3246 dari semua $Y$ Observasi yang ada yaitu ulangan $1 \quad(31,9)$ ulangan 2 (22) dan ulangan $3(38,1)$. Perlakuan nilai EC 3 pada bobot basah tanaman selada varietas 2 menunjukan hasil $Y$ Model yang sama yaitu 27, 3259 dari semua $Y$ Observasi yang ada yaitu ulangan 1 (24); ulangan 2 (24,5); dan ulangan $3(28,2)$. Perlakuan nilai EC 4 pada bobot basah tanaman selada varietas 2 
menunjukan hasil $Y$ Model yang sama yaitu 27, 3271 dari semua $Y$ Observasi yang ada yaitu ulangan $1 \quad(13,6)$ ulangan $2(36,6)$ dan ulangan 3 (27).

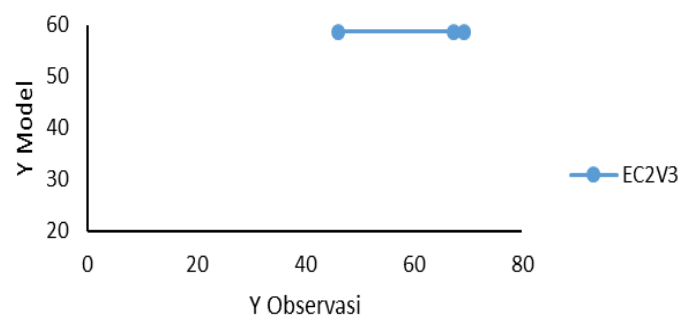

Gambar 16. Grafik Permodelan Matematik Bobot Basah Tanaman Selada Varietas 3 dengan Perlakuan EC2

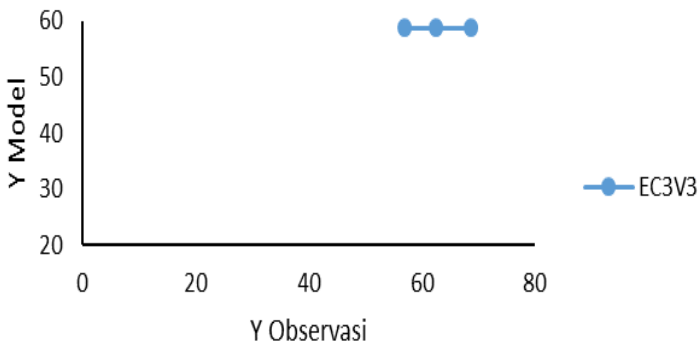

Gambar 17. Grafik Permodelan Matematik Bobot Basah Tanaman Selada Varietas 3 dengan Perlakuan EC3

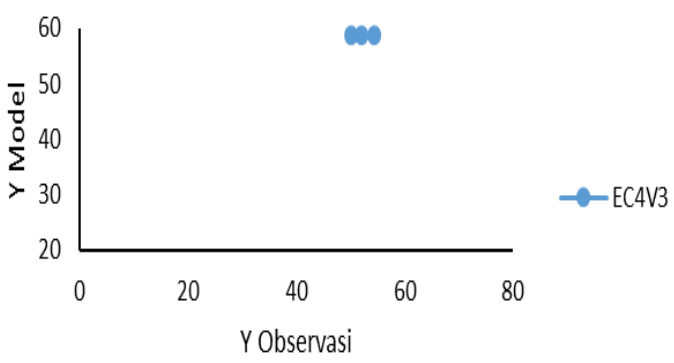

Gambar 18. Grafik Permodelan Matematik Bobot Basah Tanaman Selada Varietas 3 dengan Perlakuan EC4

Pengaruh perlakuan nilai EC 2 pada bobot basah tanaman selada varietas 3 menunjukan hasil $Y$ Model yang sama yaitu 58, 7139 dari semua $Y$ Observasi yang ada yaitu ulangan $1 \quad(67,3)$ ulangan $2(46,2)$ dan ulangan $3(69,2)$. Perlakuan nilai EC 3 pada bobot basah tanaman selada varietas 3 menunjukan hasil $Y$ Model yang sama yaitu 58, 7176 dari semua $Y$ Observasi yang ada yaitu ulangan $1 \quad(62,5)$ ulangan 2 (57) dan ulangan $3(68,7)$. Perlakuan nilai EC 4 pada bobot basah tanaman selada varietas 3 menunjukan hasil $Y$ Model yang sama yaitu 58, 7213 dari semua $Y$ Observasi yang ada yaitu ulangan $1 \quad(50,2)$ ulangan $2(52)$ dan ulangan $3(54,5)$.
Grafik model matematik jumlah daun tanaman varietas 1 disajikan pada gambar 19 , 20, dan 21, grafik model matematik jumlah daun tanaman varietas 2 disajikan pada gambar 22, 23, dan 24, sedangkan grafik model matematik jumlah daun tanaman varietas 3 disajikan pada gambar 25, 26, dan 27. Hasil analisis persamaan matematik bobot basah tanaman dari 3 varietas disajikan dalam tabel 9 sampai dengan 16 .
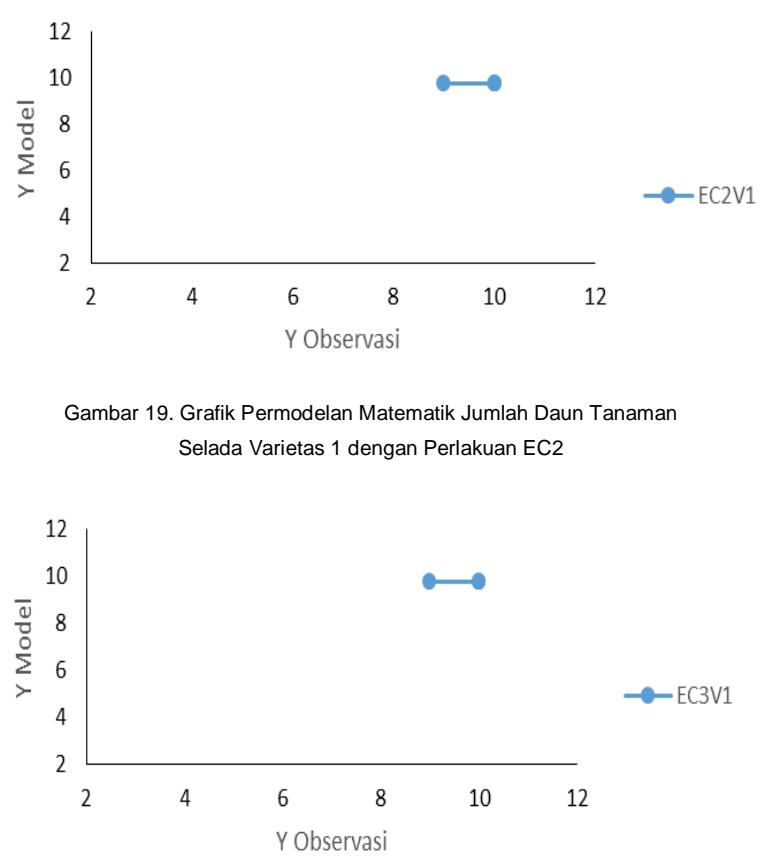

Gambar 20. Grafik Permodelan Matematik Jumlah Daun Tanaman Selada Varietas 1 dengan Perlakuan EC3

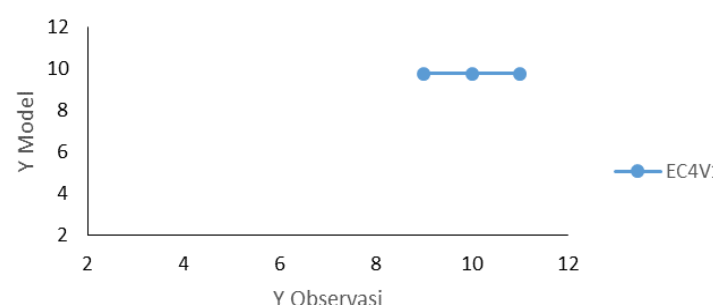

Gambar 21. Grafik Permodelan Matematik Jumlah Daun Tanaman Selada Varietas 1 dengan Perlakuan EC4

Pengaruh perlakuan nilai EC 2 pada jumlah daun tanaman selada varietas 1 menunjukan hasil $Y$ Model yang sama yaitu 9,7784 dari semua $Y$ Observasi yang ada yaitu ulangan 1 (10) ulangan 2 (10) dan ulangan 3 (9). Perlakuan nilai EC 3 pada jumlah daun tanaman selada varietas 1 menunjukan hasil $Y$ Model yang sama yaitu 9,7787 dari semua $Y$ Observasi yang ada yaitu ulangan 1 (10) ulangan 2 (9) dan 
ulangan 3 (10). Perlakuan nilai EC 4 pada jumlah daun tanaman selada varietas 1 menunjukan hasil $Y$ Model yang sama yaitu 9,7791 dari semua $Y$ Observasi yang ada yaitu ulangan 1 (11) ulangan 2 (9) dan ulangan 3 (10).

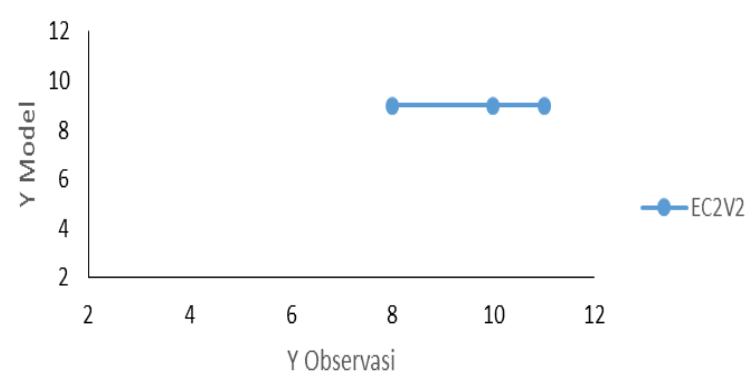

Gambar 22. Grafik Permodelan Matematik Jumlah Daun Tanaman Selada Varietas 2 dengan Perlakuan EC2

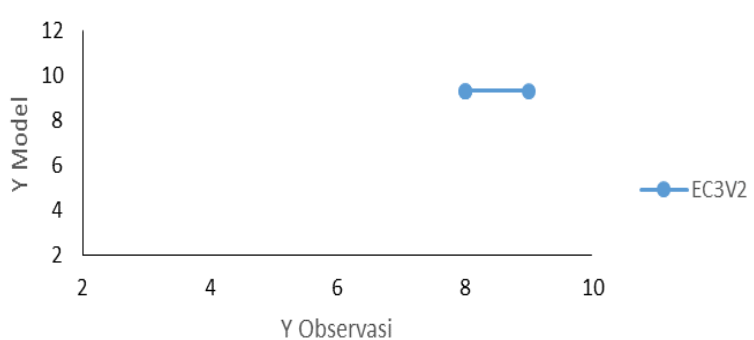

Gambar 23. Grafik Permodelan Matematik Jumlah Daun Tanaman Selada Varietas 2 dengan Perlakuan EC3

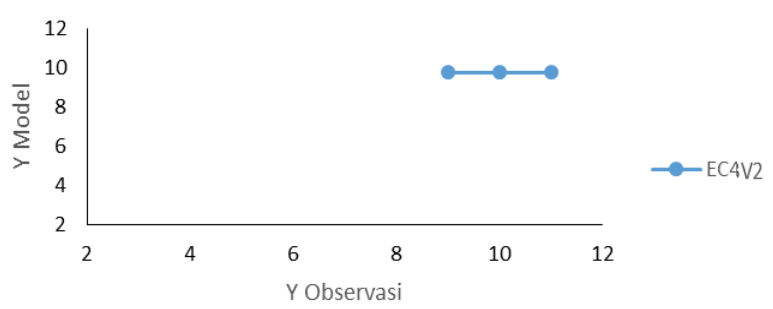

Gambar 24. Grafik Permodelan Matematik Jumlah Daun Tanaman Selada Varietas 2 dengan Perlakuan EC4

Pengaruh perlakuan nilai EC 2 pada jumlah daun tanaman selada varietas 2 menunjukan hasil $Y$ Model yang sama yaitu 8 , 9850 dari semua $Y$ Observasi yang ada yaitu ulangan 1 (10) ulangan 2 (8) dan ulangan 3 (11). Perlakuan nilai EC 3 pada jumlah daun tanaman selada varietas 2 menunjukan hasil Y Model yang sama yaitu 9, 3199 dari semua Y Observasi yang ada yaitu ulangan 1 (9) ulangan 2 (8) dan ulangan 3 (8). Perlakuan nilai EC 4 pada jumlah daun tanaman selada varietas 2 menunjukan hasil $Y$ Model yang sama yaitu 9, 6672 dari semua $Y$ Observasi yang ada yaitu ulangan 1 (8) ulangan 2 (11) dan ulangan 3 (10).

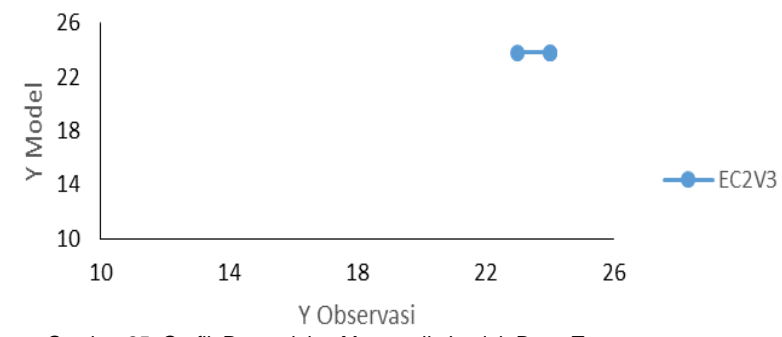

Gambar 25. Grafik Permodelan Matematik Jumlah Daun Tanaman Selada Varietas 3 dengan Perlakuan EC2

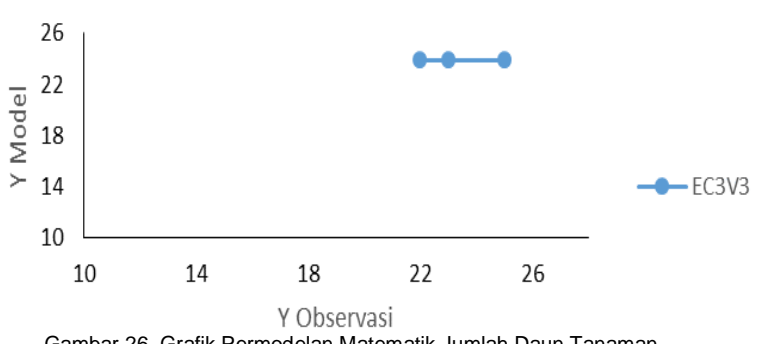

Gambar 26. Grafik Permodelan Matematik Jumlah Daun Tanaman Selada Varietas 3 dengan Perlakuan EC3

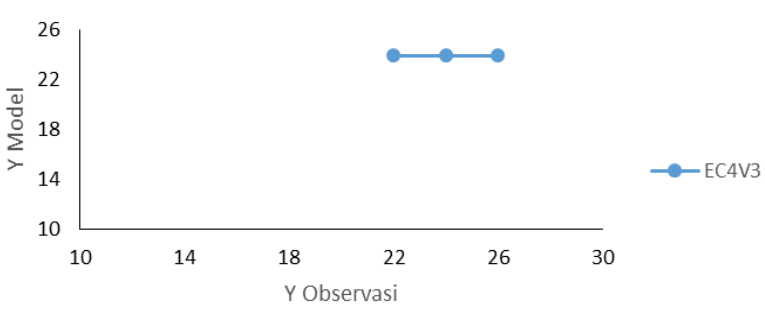

Gambar 27. Grafik Permodelan Matematik Jumlah Daun Tanaman Selada Varietas 3 dengan Perlakuan EC4

Pengaruh perlakuan nilai EC 2 pada jumlah daun tanaman selada varietas 3 menunjukan hasil $Y$ Model yang sama yaitu 23, 8225 dari semua $Y$ Observasi yang ada yaitu ulangan 1 (24) ulangan 2 (24) dan ulangan 3 (23). Perlakuan nilai EC 3 pada jumlah daun tanaman selada varietas 3 menunjukan hasil $Y$ Model yang sama yaitu 23, 9008 dari semua $Y$ Observasi yang ada yaitu ulangan 1 (23) ulangan 2 (25) dan ulangan 3 (22). Perlakuan nilai EC 4 pada jumlah daun tanaman selada varietas 3 menunjukan hasil $Y$ Model yang sama yaitu 23, 9794 dari semua $Y$ Observasi yang ada yaitu ulangan 1 (22) ulangan 2 (26) dan ulangan 3 (24).

\section{Pembahasan Umum Persamaan}

Berdasarkan hasil analisis persamaan matematik bobot basah tanaman maupun jumlah daun tanaman selada pada semua perlakuan nilai EC ((P1:EC $2 \mathrm{mS} / \mathrm{cm})$; (P2:EC 3mS/cm); dan (P3:EC $4 \mathrm{mS} / \mathrm{cm}$ ) dan pada semua perlakuan varietas (New grand 
rapids (V1), Red ava (V2) dan Chris green (V3)), hasil yang diperoleh menunjukan nilai yang hampir sama pada tiap-tiap perlakuan. Data nilai EC yang sama untuk 3 ulangan memberikan nilai $Y$ model yang sama pada perbedaan nilai EC. Nilai $Y$ model sedikit mengalami perubahan namun tidak terlalu signifikan. Perubahan terjadi hanya pada angka ke 4 dibelakang koma.

Hasil ini diduga karena nilai faktor luar yang sama, seperti nilai ph (derajat keasaman) dengan angka 6 , nilai rata-rata suhu yang sama dalam satu bulan pelaksaan penelitian yaitu $32,1{ }^{\circ} \mathrm{C}$, serta nilai rata-rata kelembaban yang sama yaitu $65 \%$ selama penelitian. Data ini kemudian digunakan untuk menghitung semua perlakuan yang hanya berbeda pada nilai EC dan jenis varietas. Nilai yang sama ini diperoleh karena semua tanaman yang diteliti berada pada satu lingkungan yang sama dimana pelaksanaan penelitian dilakukan didalam screen house berbentuk piggy back. Hal ini mengakibatkan nilai error yang diperoleh tidak bisa mendekati nol. Diperlukan adanya data yang lebih banyak untuk bisa memperoleh nilai error yang lebih kecil atau mendekati nol.

Hasil analisis persamaan matematik bobot basah tanaman selada varietas 1 , varietas 2 dan varietas 3 diperoleh nilai error berturut-turut sebesar V1 $(18,29)$; V2 $(459,73)$ dan V3 $(592,79)$, sedangkan Hasil analisis persamaan matematik jumlah daun tanaman selada Varietas 1 , varietas 2 dan varietas 3 diperoleh nilai error berturut-turut sebesar $\mathrm{V} 1$ $(3,55) ;$ V2 $(14,31)$; dan V3 $(14,37)$. Metode yang digunakan untuk menilai nilai error adalah metode RMSE (Root Mean Square Error). RMSE merupakan nilai rata-rata dari jumlah kuadrat kesalahan, juga dapat menyatakan ukuran besarnya kesalahan yang dihasilkan oleh suatu model prakiraan. Nilai RMSE rendah menunjukan bahwa variasi nilai yang dihasilkan oleh suatu model prakiraan mendekati variasi nilai observasinya. Menurut Makridakis, et al (1982) salah satu ukuran kesalahan dalam peramalan adalah nilai tengah akar kuadrat atau Root Mean Square Error (RMSE).

\section{KESIMPULAN}

1. Perlakuan varietas menunjukan hasil sangat nyata pada variabel jumlah daun, volume akar, kadar klorofil, bobot basah tanaman, bobot basah akar dan varietas selada yang memberikan hasil terbaik untuk sistem hidroponik rakit apung dengan melihat variabel tinggi tanaman, jumlah daun, volume akar, kadar klorofil, panjang akar, bobot basah tanaman, dan bobot basah akar adalah varietas Chris green (V3)

2. Perlakuan nilai EC menunjukan hasil sangat nyata pada variabel $\mathrm{N}$ total jaringan dengan nilai EC 4 (P3) dan hasil yang diperoleh yaitu $1,32 \%$.

3. Model persamaan matematik dengan fungsi Cobb-Douglas belum bisa memvalidasi data penelitian dikarenakan error tinggi, sehingga $Y$ Model tidak mengikuti Y Observasi.

\section{DAFTAR PUSTAKA}

Bastian, H., S. A. Adimihardja dan Setyono. 2013. Efektifitas Komposisi Pupuk Anorganik dan Pupuk Organik terhadap Pertumbuhan dan Produksi Dua Kultivar Selada (Lactuva Sativa L.) dalam Sistem Hidroponik Rakit Apung. Jurnal Pertanian 4 (2): 91-99.

Erina, Y. 2007. Pengaruh Pengaturan EC (Electro-conductivity) dan Jarak Tanam Terhadap Petumbuhan dan Hasil Tanaman Caisim (Brassica juncea L.) pada Sistem Aeroponik. Skripsi. Fakultas Pertanian. Universitas Negeri Surakarta. Surakarta.

Gardner, P. Franklin, B. R. Pearce dan R. L. Mitchell. 2007. Fisiologi Tanaman Budidaya. Terjemahan oleh Herawati, Susilo. Universitas Indonesia. Jakarta. 
Harjoko, D. 2007. Studi Macam Sumber Air dan $\mathrm{pH}$ Larutan Nutrisi terhadap Pertumbuhan dan Hasil Tanaman Sawi (Brassica juncea L.) secara Hidroponik NFT. Makalah Seminar Nasional Hortikultura. Fakultas Pertanian. Universitas Negeri Surakarta. Desember 2007.

Haryanto, E. 2003. Sawi dan Selada. Penebar Swadaya, Jakarta.

Hochmuth, G. 2003. Fertilizer Management of Greenhouse Vegetables-Florida Greenhouse Vegetable Production. Handbook, Vol 3; University of Florida, Institut of Food and Agricultural Science, Florida.

Jasmi, E. Sulistyaningsih dan D. Indradewa, 2013. Pengaruh Vernalisasi Umbi terhadap Pertumbuhan, Hasil dan Pembungaan Bawang Merah (Allium cepa L. Aggregatum group) di Dataran Rendah. Jurnal IImu Pertanian 16(1): $42-57$

Jones. S.B \& A,E Luchsinger. 1987. Plant Systematics. New York: McGraw-Hill.Inc.

Kastono, D. H.S dan Siswandono. 2005. Pengaruh Nomor Ruas Setek dan Dosis Pupuk Urea Terhadap Pertumbuhan dan Hasil Kumis Kucing. Jurnal IImu Pertanian. Vol 12 (2): 78-83.

Lahadassy. J., Mulyati A.M dan A.H Sanaba. 2007. Pengaruh Konsentrasi Pupuk Organik Padat Daun Gamal terhadap Tanaman Sawi. Jurnal Agrisistem 3 (2): 80-89.

Lingga, P. 2005. HIDROPONIK Bercocok Tanam Tanpa Tanah. Penebar Swadaya. Jakarata. 80 hal.
Makridakis, S. 1982. The Accuracy of Extrapolative (Time Series Methods): Results of a Forecasting Competition. Journal of Forecasting (1) : 111153.

Manuhuttu A. P., H. Rehatta, dan J. J. G. Kailola. 2014. Pengaruh Konsentrasi Pupuk Hayati Bioboost Terhadap Peningkatan Produksi Tanaman Selada (Lactuva sativa L.). Jurnal Agrologia (3): 18-27.

Mas'ud, Hidayati. 2009. Sistem Hidroponik Dengan Nutrisi dan Media Tanam Berbeda Terhadap Pertumbuhan dan Hasil Selada. Media Litbang Sulteng 2 (2): 131-136.

Morgan, L. 2000. The $p H$ Factor in Hydroponics. Edisi Amy knuston The Best of The Growing Edge. New Moon publ. Inc. Corvallis.

Nugraha, R. U., 2014. Sumber Hara Sebagai Pengganti $A B$ mix pada Budidaya Sayuran Daun Secara Hidroponik. Skripsi. Tidak dipublikasikan. Departemen Agronomi Dan Holtikultura : Institut Pertanian Bogor.

Palupi E. R dan Y. Dedywiryanto, 2008. Kajian Karakter Toleransi Cekaman Kekeringan pada Empat Genotipe Bibit Kelapa Sawit (Elaeis guineensis Jacq). Buletin Agronomi 3 (6): 24-32.

Plaster E. J. 2003. Soil Science and Management. Delmar Learning Inc. 4th ed United States. 384 p.

Riris. 2009. Jambu Air Citra Kebanggaan Indonesia. (On-line). http://st303009.sitekno.com/artic le/63119/jambu-air-citrakebanggaan-indonesia.html diakses 28 April 2018. 
Ruhnayat, A. 2007. Penentuan Kebutuhan Pokok Unsur Hara N, P, K Untuk Pertumbuhan Tanaman Panili (Vanilla planifolia Andrews). Buletin Littro (Online) http:balittro.litbang.deptan.go.id/i nd/images/stories/Buletin/.../5pa nili.pdf, diakses tanggal 27 Oktober 2016.

Sastradiharja. S. 2011. Praktis Bertanam Selada dan Ansewi Secara Hidroponik. Bandung: Penerbit Angkasa Bandung. Hal. 1-17.

Sitompul, S.M dan B. Guritno. 2005. Analisis Pertumbuhan Tanaman. Gadjah Mada University Press. Yogyakarta.

Soekartawi. 1993. Teori Ekonomi Produksi Analisa Fungsi Cobb-Douglass; Sebuah bahasan khusus. Rajawali Press, Jakarta.
Suleman D, Cindra. 2013. Pertumbuhan dan Produksi Tanaman Sawi (Brassica juncea L.) dengan Pemberian Dosis Pupuk Organik Kotoran Ayam. Skripsi. Fakultas IImu-IImu Pertanian. Universitas Negeri Gorontalo. 2013.

Sulistyaningsih, E., B. Kurniasih, E. Kurniasih. 2005. Pertumbuhan dan Hasil Tanaman Caisim pada Berbagai Warna Sungkup Plastik. IImu Pertanian 12 (1): 65-76.

Sunu, P dan Waryoto. 2006. Dasar Hortikultura. UNS Press. Surakarta.

Wasonowati, C., S. Suryawati, A. Rahmawati, 2013. Respon Dua Varietas Tanaman Selada (Lactuva sativa L.) terhadap Macam Nutrisi pada Sistem Hidroponik. Jurnal Agrovigor 6 (1): 50-56. 